\title{
Consumption Responses to a Large Shock to Financial Wealth: Evidence from Italy*
}

[Suggested running head: Consumption responses to wealth shocks in Italy]

\author{
Renata Bottazzi \\ University of Bologna, 40126 Bologna, Italy. renata.bottazzi@unibo.it
}

\section{Serena Trucchi}

Ca' Foscari University of Venice, 30121 Venice, Italy. serena.trucchi@unive.it

\section{Matthew Wakefield}

University of Bologna, 40126 Bologna, Italy. matthew.wakefield@unibo.it

\begin{abstract}
We estimate marginal propensities to consume from wealth shocks. We exploit large assetprice shocks in 2007-2008 and household-level panel data to implement instrumental variables. A euro fall in risky financial wealth resulted in cuts in annual total (non-durable) consumption of 8.5-9 (5.5-5.7) cents, with small effects on food spending. Effects seem stronger for lower-wealth or indebted households, but significant responses from wealthier households and those without mortgages are important for our baseline results.

Counterfactuals indicate financial-wealth effects were relatively important for consumption falls in 2007/08 Italy. The estimated effects are consistent with a simulated lifecycle model capturing the wealth shock.
\end{abstract}

Key words: Wealth effects; marginal propensity to consume; household consumption; the Great Recession.

JEL codes: D12, D15, E21.

\footnotetext{
*Financial support: MIUR-PRIN-2010-11-2010T8XAXB_006; MIUR-FIRB-2008-RBFR089QQC-003J31J10000060001; E.U. Marie Sklodowska-Curie agreement 655770. We thank: Orazio Attanasio, Richard Blundell, Tom Crossley, Maria Cristina De Nardi, Richard Disney, Carl Emmerson, Ben Etheridge, Erik Hurst, Brian Kovak, Andrea Neri, Luca Nunziata, Luigi Pistaferri, Davide Raggi, two excellent referees, seminar participants. Bottazzi and Wakefield are IFS Fellows.

This article has been accepted for publication and undergone full peer review but has not been through the copyediting, typesetting, pagination and proofreading process, which may lead to differences between this version and the Version of Record. Please cite this article as doi:
} 


\section{Introduction}

Household consumption spending is the largest single component of modern market-based economies, often representing more than half of GDP. ${ }^{1}$ Understanding the determinants of consumption spending is therefore of crucial interest and importance and there is a very extensive literature studying how spending responds to resource shocks and specifically, as in this paper, to wealth shocks.

As is clear from excellent surveys by Poterba (2000) and Paiella (2009), empirical evidence on the relationship between wealth and consumption spending has come from both aggregate, time-series studies, and studies that exploit household-level data. ${ }^{2}$ Carroll et al. (2011) discuss potential limitations of relying purely on aggregate data and also conditions under which micro-data could be helpful. 'Micro' studies have potential to add insight and sharpen identification when detailed (and preferably panel) data on household finances and consumption spending are available and when an exogenous source of variation in wealth can be found. Our contribution to the literature comes from exploiting data with precisely these features.

The data we use come from the Bank of Italy's Survey on Household Income and Wealth (SHIW), and contain rich information on households' asset holdings (values and ownership), consumption outcomes, and demographic and economic characteristics. The survey sample is designed to be representative of the Italian resident population and has a panel component. This combination of characteristics is impressive by international standards and makes our study of broad interest for understanding the importance of wealth effects in

${ }^{1}$ OECD figures (OECD 2018) for 2016 put this proportion at 53\% in the euro area, 54\% for Italy and $67 \%$ for the US (these figures are based on the series for "household final consumption spending").

${ }^{2}$ Even studies based on aggregate time-series evidence have long acknowledged that allowing for different types of consumers has important implications when comparing models to the data (see Campbell and Mankiw, 1989). 
consumption. Having wealth and consumption in a household-level panel data, together with a potentially exogenous wealth shock, also facilitates identification through

instrumental variables (IV).

The wealth shock comes from the 2006 - 10 period that we choose as the object of our study. Italy's FTSE-MIB fell by more than 60\% between May 2007 and March 2009, with a large part of this fall in the central months of $2008 .^{3}$ Households that held wealth in stocks thus suffered a sudden, potentially large and mostly unanticipated shock to their financial wealth. ${ }^{4}$ We use the idea that the 2008 shock to asset values can provide a source of variation in wealth that is exogenous to households' consumption behaviour, to build an IV estimator similar to that of Banks et al (2012); our estimator is discussed in detail in section III.

Our study is related to other papers that have aimed to estimate the importance of wealth effects in driving consumption behaviour since $2007 .{ }^{5}$ As just mentioned, our study is similar in methodology to the England-based analysis of Banks et al. (2012). Those authors have less comprehensive data on spending than we do and a sample of agents aged $50+$. They find only modest effects of wealth shocks on household spending during the crisis but are also able to analyse wealth effects on outcomes that we do not observe. More tightly

\footnotetext{
${ }^{3}$ The evolution of stock prices in Italy is documented in more detail in Online Appendix Figure B2 (see page 4 of our supplementary material). The figure also illustrates that the path of aggregate consumption closely shadowed that of the stock market, and if anything slightly lagged the fall in stock prices.

${ }^{4}$ It is worth noting that, unlike in the US and UK, house values in Italy did not suffer large falls near the beginning of the Great Recession (Agenzia del Territorio, 2012), and this explains our emphasis on the effects of financial wealth.

${ }^{5}$ There are broader studies of consumption in the Great Recession. See, for example, Crossley, Low and O'Dea (2013) for the UK; and Petev, Pistaferri and Saporta-Ecksten (2011) and De Nardi, French and Benson (2012) for the US. For Italy, Celidoni, De Nadai and Weber (2016) look at how consumption and other outcomes deviated in later years from predictions based on the behaviour of cohorts up to 2006. Rodano and Rondinelli (2014) compare recent recessions and report that the Bank of Italy's quarterly model does not indicate a strong role for wealth in aggregate consumption in 2006-08. However, the absence of a fall in house prices means that the model's measure of financial plus real wealth does not decline in the relevant years. While not focussing on financial wealth effects, both these papers do describe evidence in micro data of the falls in the value of (financial) wealth up to 2008 that provide our source of variation.
} 
focussed on consumption is the influential study of the U.S. by Mian, Rao and Sufi (2013), who estimate a marginal propensity to consume out of housing wealth of $5-7$ per cent for 2006-09 that is robust to instrumenting using geographical constraints on housing supply. They also find that this propensity to consume is larger where households have higher mortgage loan-to-value ratios. In another important analysis of the US, Christelis, Georgarakos and Jappelli (2015) look at how losses on financial wealth and in real wealth, and unemployment, affected consumption in an older (50+) sample in 2008-09. Using data that ask households to report capital losses on different assets, they find a marginal propensity to consume out of financial wealth of around 3.3 per cent (and smaller effects for losses on housing). In an interesting recent study, Paiella and Pistaferri (2017) use Italian data for 2008-10 to decompose wealth effects into responses to unanticipated and anticipated changes in wealth. They find wealth effects of around 3 per cent that are similar for anticipated and unanticipated changes and driven by responses to house prices. The time period that these authors exploit provides consistent expectations variables, but does not include that large shock to financial asset values that is a key element of our identification strategy. ${ }^{6}$

Precisely stated, our research goal is to estimate the marginal propensity to consume $\left(\mathrm{mpc}^{7}\right)$ out of a shock to financial wealth. A preview of key results is as follows. A one euro fall in risky financial wealth resulted in households cutting annual total consumption spending by between 8.5 and 9 cents, and slightly more than 5.5 cents of this cut was in

\footnotetext{
${ }^{6}$ From the large set of studies on wealth effects in consumption that pre-date the 2007-08 asset price shock, the most relevant here are those based on Italy. Somewhat in line with our analysis based on shocks, Guiso, Paiella and Visco (2005) aim to estimate the effects of capital gains; they also investigate the long-run relationships between wealth and consumption. Paiella (2007) uses pooled cross-sections of data to estimate long-run marginal propensities to consume from different forms of wealth, while Calcagno, Fornero and Rossi (2009) focus on the effects of real estate wealth.

7 We use "mpc" indifferently for "marginal propensity to consume" and "marginal propensities to consume". Context should reveal whether we have a singular or a plural.
} 
spending on non-durables. We find effects of around 1.5 cents for food spending.

Counterfactual simulations from our regressions indicate that financial wealth effects were an important driver (relative to other factors) of consumption falls in our sample. We also show that the estimated propensity for total consumption to respond to the negative wealth shock is consistent with the predictions of a dynamic-stochastic lifecycle model that is constructed to capture features of the period of our data. Finally, we find tentative evidence in line with the hypothesis that responses to wealth shocks were stronger for lower-wealth households or those with mortgage debt, but we also see that the responses of wealthier households and those without mortgages were important in generating our main results.

The paper is organised as follows. Section II introduces the dataset that we use and provides some data descriptives. Section III explains our research method, describing both our IV estimator and a key variable that must be constructed to implement this estimator. Section IV presents and discusses our main results on wealth effects. We first present average wealth effects for broad measures of consumption, then results for finer spending categories. In the final part of Section IV, we look at how the estimated wealth effects vary with wealth levels or with exposure to mortgage debt. Section $V$ concludes.

\section{Data}

The Survey on Household Income and Wealth (SHIW) is a representative sample of the Italian resident population. The survey is conducted every other year and covers about 24,000 individuals and 8,000 households ${ }^{8}$. There is a panel component to the survey sample as approximately half of households in a given year are re-interviewed at least once in subsequent years.

\footnotetext{
${ }^{8} \mathrm{~A}$ household is a group of individuals related by blood, marriage or adoption and sharing the same dwelling.
} 
The survey records a rich set of household and person characteristics as well as information on incomes and savings, and on household expenditure and wealth. Wealth data is rich, containing both participation and value for a range of financial assets, housing wealth, and businesses. For the purpose of our analysis, we use data for the years 20042010. In this way we are able to observe changes in wealth and consumption between 2006 and 2008, and between 2008 and 2010, and to construct our instrumental variable using information on household portfolios from the 2004 and 2006 surveys. Given our methodology, having information that spans the period of the large adjustment to financial asset values in $2007-08$, is particularly important.

We now describe the SHIW consumption and wealth variables that we exploit.

SHIW consumption variables. The SHIW dataset records consumption spending on four different categories of products. Total consumption is the sum of two other categories, namely durable (means of transport, furniture, household appliances, etc.) and non-durable expenditures. Food consumption is a subclass of non-durable spending and includes meals at home or eaten out. In our analyses we always measure expenditures annually and in real terms (2010 euros, based on the Household Index of Consumer Prices provided by Istat).

Descriptive statistics on consumption in our sample are shown in Table 1. Average total consumption decreases between 2004 and 2010, but the drop is statistically significant at 1\% only between 2006 and 2008. This drop is largely driven by non-durable expenditure that significantly decreases by more than 600 euros between 2006 and 2008, with almost 400 euros of this change coming from food consumption. Durable consumption displays a slightly different pattern, decreasing significantly (by approximately 300 euros on average) only in 2010. 
Table 1: Descriptives of consumption in our sample

\begin{tabular}{llcccc}
\hline $\begin{array}{l}\text { Consumption } \\
\text { expenditure: }\end{array}$ & Total & Non-durables & Durables & Food \\
\hline $\mathbf{2 0 0 4}$ & Mean & 18784 & 16630 & 2154 & 7074 \\
& (St. dev.) & $(12589)$ & $(9103)$ & $(7205)$ & $(3676)$ \\
2006 & Mean & $18304^{*}$ & 16411 & $1893^{*}$ & $6918^{*}$ \\
& (St. dev.) & $(11179)$ & $(8528)$ & $(5773)$ & $(3433)$ \\
2008 & Mean & $17541^{* * *}$ & $15796 * * *$ & 1745 & $6522^{* * *}$ \\
& (St. dev.) & $(10515)$ & $(7943)$ & $(5210)$ & $(3108)$ \\
2010 & Mean & 17295 & 15859 & $1436^{* * *}$ & $6391^{*}$ \\
& (St. dev.) & $(9945)$ & $(8130)$ & $(4149)$ & $(3064)$ \\
\hline
\end{tabular}

Notes to Table: 3047 observations in 2004; 3867 in 2006; 3865 in 2008 and 3323 in 2010.

Stars refer to the significance of the test on equality of mean consumption in the current and previous wave (with equal variances): ${ }^{*} p<0.1,{ }^{* *} p<0.05,{ }^{* * *} p<0.01$.

Comparing the SHIW data to aggregate statistics (see Online Appendix B), we see a very good alignment for non-durable and food spending but diverging patterns for durable consumption after 2009 . This is reflected in the patterns for total consumption, which line up best up to 2008. Nonetheless, given that our estimates rely particularly on variation in the $2006-08$, we find the comparison to aggregate data reassuring.

SHIW financial wealth variables. The SHIW dataset collects detailed information on household portfolios. Respondents are asked about ownership of, and about amounts of wealth held in, each of many types of asset. Assets are grouped in broad categories: cash (bank accounts and saving certificates); Italian government bonds (with different durations); domestic bonds and investment funds; Italian shares; foreign bonds and shares; and, other minor categories. Within each broad category individuals are asked about a detailed set of assets. SHIW also provides information on household wealth in several types of mutual funds, and these funds can be categorised according to the extent to which they expose the holder to stock-market risk.

If survey respondents report that they hold an asset, they are then asked about how much wealth they held in that asset at the $31^{\text {st }}$ of December in the year after which the 
survey wave is named (i.e. December $31^{\text {st }} 2008$ for the " 2008 SHIW"). ${ }^{9}$ Respondents are first asked to indicate in to which of several bands of value their asset fell and then to report a point amount for this value. Failure to report a point amount results in the household being asked whether the value of their holding is nearer to the bottom, middle or top of the band. Since not all individuals give a point amount we use some imputed values for wealth. In imputation we use band and bottom/middle/top information to allocate values by asset. ${ }^{10}$

Since our main regressions are in first-differences (see Section III) we have to be careful about the fact that imputation could considerably increase noise to signal ratio, especially for cases where individuals report holdings in the relatively broad top bands of asset values. For this reason in our sample selection we exclude from the sample households who do not provide a point amount and ever report being in the top bands (imputed wealth in a single asset above 150000 euros with no upper limit). Our sample selection also requires panel information for three consecutive waves (to have a difference and our instrument) and we select respondents older than 30 years. We end up with a sample of 6370 person-year observations from nearly 4000 families. ${ }^{11}$

Description of the key (change in) wealth variables that we use, and the constructed variables that instrument the wealth change, is postponed until after the outline of our empirical setup.

\footnotetext{
${ }^{9}$ Having end of year wealth means we have data on households at close to the top of the stock market (at the end of 2006) and at close to the bottom of the crash (at the end of 2008).

${ }^{10}$ To have a homogeneous measure of asset values we do not use imputed values provided by the Bank of Italy, since they are not available for the 2004 wave. We need to rely on imputation by the Bank of Italy for (the sum of) three types of deposit in 2006, since information on the band they belong to is not available. The results of Section IV are not sensitive to substituting Bank of Italy imputation for our imputation as far as possible.

${ }^{11}$ We also experimented with tighter selection criteria; results are not reported but are available on request.
} 


\section{Research Method}

\section{Empirical and Conceptual Setup}

The conceptual basis for our research, and a useful framework for interpreting empirical results, is the lifecycle model of consumption and saving. The simplest version of this model, with certainty and full transferability of resources between periods, predicts that agents consume a certain proportion of their lifetime wealth (financial, physical and human wealth) in each period. To estimate this propensity to consume out of wealth, one could estimate the relationship between household consumption and household wealth in levels. An alternative, used, for example, by Dynan and Maki (2001) and Banks et al. (2012), is to take first differences ${ }^{12}$ and regress the change in household consumption on the change in household financial wealth:

$$
\Delta c_{h t}=\alpha+\omega \Delta w_{h t}+\varepsilon_{h t}
$$

where: subscripts $h$ and $t$ denote household and time period respectively; $\Delta c_{h t}$ is the first difference of real consumption spending equal to $c_{h t}-C_{h(t-1) ;} \Delta W_{h t}$ is the similarly defined first difference in real wealth; $\alpha$ is a model parameter and $\varepsilon$ is the regression error term; and, $\omega$ is the parameter of interest which captures the propensity to consume out of wealth.

The specification in differences has some empirical advantages. First, if one can measure a change in wealth which plausibly captures the change in value of the whole household portfolio, then this can be related to the change in consumption to provide a measure of the propensity to consume, even if the values of some elements of the portfolio (such as human wealth) are not accurately observed. This potentially reduces the informational burden of the estimator. Second, a large change in the value of one form of wealth will provide helpful variation to estimate the relationship of interest: the sudden fall

\footnotetext{
12 In our data first differences are two-year changes.
} 
in the value of some financial assets in 2007-2008 provides us with this kind of variation.

We are aiming to estimate the marginal propensity to consume $(\mathrm{mpc})$ out of (or to reduce consumption due to) a wealth shock. In order to properly identify this parameter, there is an endogeneity issue that must be dealt with. Suitable conditions for identification would include that the change in wealth is an exogenous (to the change in consumption) shock. However, if resources can be either saved or spent then the problem of endogeneity is that, all else equal, an individual who accumulates more wealth will enjoy a smaller change in consumption (which may be a bigger drop). This negative correlation between $\Delta c$ and $\Delta W$ is a mechanical implication of the dynamic budget constraint and not the causal relationship from wealth to consumption that we wish to identify. Estimation that does not take this into account will tend to yield downward-biased estimates of the mpc.

A method of dealing with this endogeneity that dates back at least to Dynan and Maki (2001) is the idea of regressing the change in consumption on the "passive" part of the change in wealth, which is that part that comes from capital gains rather than from active consumption/saving decisions. Banks et al. (2012) shares the idea of relating the change in consumption to a change in wealth that is not generated by active saving behaviour or portfolio adjustments, but uses this as the basis of an instrumental variables estimator. ${ }^{13}$ Our data are similar in structure to those used by Banks et al. (2012), and we also implement an instrumental variables estimator. The estimator is based on taking a fixed wealth portfolio for each household, and calculating how the value of this portfolio would have changed due to changes in asset values and in the absence of any active saving or dissaving by the household. More concretely, consider calculating the change in the value of

\footnotetext{
${ }^{13}$ One of the authors of that paper has also applied the idea of using changes in wealth from asset price shocks to instrument changes in wealth, in an analysis of the impact of wealth shocks on retirement plans; see Crawford (2013).
} 
this fixed portfolio (hereafter "the calculated change in wealth") for an individual whose change in consumption and wealth are observed for the period 2006 to 2008 . A candidate fixed portfolio is the amounts of assets held in 2006. The household might have a certain amount of cash deposits, domestically held shares, and domestically held bonds. ${ }^{14}$ Real values for these holdings by the end of 2008 can be calculated by applying the relevant real interest rate to the cash deposits, and the real change in the relevant price index for stocks and bonds, to up- (or down-) rate the values of the initial holdings. This will give a final value of the portfolio, and the calculated change in wealth is this final value less the initial value of the portfolio.

This measure of calculated changes in wealth can be expected to be correlated with actual changes in wealth and is unaffected by active saving decisions and thus free of the mechanical relationship between wealth and consumption changes that we described above. Thus the calculated change in wealth is the ideal "excluded variable" to construct an instrument for actual changes in wealth.

The instrumental variables (IV) estimator just described should consistently estimate the relationship we want to identify between wealth shocks and consumption. The key exogenous variation in wealth that is being exploited is that generated by asset price changes. One way to justify that such changes come as shocks would be to note that asset price movements are highly persistent (permanent), so that the best guess of future prices are current prices and deviations from this are surprises. Furthermore, in our case the biggest source of variation in asset prices comes from the 2007-2008 stock-market crash and it seems reasonable to suppose that price falls in this period were largely unanticipated

\footnotetext{
${ }^{14}$ The list of asset classes used in our empirical application, and the price indices and interest rates that we apply to them, are described in Online Appendix A.
} 
(especially by individuals who remained in the stock market). ${ }^{15}$ Thus the large change in asset prices in 2007-2008 is important both for providing us with variation, and for providing variation that is exogenous.

We have described the IV strategy as if the instrument for changes in wealth between $t$ and $t-1$ is based on the portfolio held at $t-1$. In fact, if there is measurement error in portfolio shares such an estimator would be subject to bias since the same measurement error affects observed wealth changes and the proposed instrument. To deal with this we take an extra lag and base the instrument on portfolio shares observed at $t-2 .{ }^{16}$ Thus, when considering the 2006 - 2008 change in wealth, we use the household's 2004 portfolio, and, for 2008 - 2010, the 2006 portfolio.

Another threat to clean identification could be an omitted variables problem if other factors that affect consumption (on average) are also correlated with the asset price shock. In this regard a powerful advantage of the first-differenced regression is that it conditions out any household fixed effect. To further mitigate this potential problem we exploit the richness of our dataset and extend specification (1) to include a vector ( $X$ - with household and time subscripts suppressed) of covariates. An additional advantage of including covariates is that it enables us to compare the influence of wealth effects to the impact of other factors in driving changes in consumption in our sample. With covariates, the main model that we estimate by two-stage least squares is: ${ }^{17}$

$$
\Delta c_{h t}=\alpha+\omega \widehat{\Delta w_{h t}}+\boldsymbol{X}^{\prime} \boldsymbol{\beta}+\varepsilon_{h t}
$$

\footnotetext{
${ }^{15} \mathrm{An}$ additional potential source of change in consumption behaviour could be a shock to the variance of asset returns alongside a shock to asset values. With our data and method we focus on the change in asset values. ${ }^{16}$ This strategy is standard in differenced panel data models and in studies of consumption and saving it is familiar from the literature on estimating log linear approximations to Euler equations (see the discussion of Attanasio and Weber, 1993, p.634, or Banks, Blundell and Tanner, 1998, especially footnote 8).

${ }^{17}$ Note that the notation for some coefficients and the error term is, for convenience, the same as in equation (1), but this should not be taken to mean that estimating (1) or the model of equations (2) and (3) will yield identical results.
} 
where: $\widehat{\Delta w_{h t}}$ is the predicted change in wealth based on the first-stage equation that has the calculated change in wealth (the change in the value of a fixed portfolio), $\Delta f p_{h t}$, as a

regressor:

$$
\Delta w_{h t}=\gamma+\varphi \Delta f p_{h t}+\boldsymbol{X}^{\prime} \boldsymbol{\delta}+\mu_{h t}
$$

When estimating the model described by equations (2) and (3), the main source of variation exploited to identify the effect of the instrumented wealth variable is heterogeneity between households in the distribution of financial wealth to different assets. ${ }^{18}$ By estimating based on data for changes in wealth and consumption between 2006 and 2008 and between 2008 and 2010, we get additional variation from the different movements in asset prices in the two periods.

\section{Reported and Calculated Changes in Wealth}

To implement the IV estimator just described, a preliminary step is the construction of the "calculated change in wealth" variables. These calculated changes are the difference in two forecasted wealth values, obtained by applying the relevant interest rates and price indices to the different asset classes in initial portfolios. ${ }^{19}$ We use calculated changes in wealth for two different portfolios: the overall portfolio of financial wealth; and, the portfolio of wealth exposed to financial market risk. ${ }^{20}$

\footnotetext{
18 There could still be a worry that the consumption behaviour of households is not exogenous to the composition of their asset portfolios. For example, risk averse households might have high levels of saving and hold safer portfolios and so exhibit low consumption growth (on average), with the opposite correlations for risk seeking households. In an attempt to allay this concern, we exploit the idea that future asset returns should not predict current consumption growth, and regress changes in consumption in our sample on changes from $t$ to $t+1$ in the value of the 'lagged' portfolio used to construct our instrument (plus our vector of covariates). We find that these leads in calculated changes in wealth are never significant as predictors of current consumption growth.

${ }^{19}$ Different interest rates or price indices were applied to: cash deposits; (two types of) short term Italian government bonds; (several types of) long-term Italian government bonds; shares in Italian traded companies; shares held overseas; Italian private bonds; and a set of other foreign assets. In addition to this, information on holdings in mutual funds and the extent to which these funds are exposed to stock-market risk allows us to up rate forecast values for holdings in funds using information on stock returns for part of the fund, and on returns to safer assets for the other part of the fund. The full set of sources for interest rates and asset price indices that we used in constructing calculated asset values is listed in Online Appendix A.

${ }^{20}$ This is mainly stock market risk and exposure can be either through direct holdings or through mutual funds.
} 
Table 2: Descriptives of the change in wealth and the calculated change in wealth

\begin{tabular}{|c|c|c|c|}
\hline \multicolumn{4}{|l|}{ Financial wealth } \\
\hline & & Changes in reported wealth & $\begin{array}{l}\text { Changes in "calculated" } \\
\text { wealth }\end{array}$ \\
\hline \multirow[t]{3}{*}{ Mean (st.dev) } & & $-248(56766)$ & $-1397(8050)$ \\
\hline & 2008 & $-1259(46455)$ & $-2829(11431)$ \\
\hline & 2010 & $678(64787)$ & $-85(909)$ \\
\hline Median & & 0 & -114 \\
\hline $25^{\text {th }}$ percentile & & -4727 & -369 \\
\hline $75^{\text {th }}$ percentile & & 5832 & -14 \\
\hline \multicolumn{2}{|c|}{ Regression coefficient } & & $\begin{array}{c}0.649 * * * \\
(0.088)\end{array}$ \\
\hline \multicolumn{4}{|c|}{ Risky financial wealth (households with risky assets in 2006) } \\
\hline & & Changes in reported wealth & $\begin{array}{l}\text { Changes in "calculated" } \\
\text { wealth }\end{array}$ \\
\hline \multirow[t]{3}{*}{ Mean (st.dev) } & & $-12814(57000)$ & $-4823(17795)$ \\
\hline & 2008 & $-24957(70442)$ & $-10678(24269)$ \\
\hline & 2010 & $-1540(37431)$ & $612(1748)$ \\
\hline Median & & -3073 & 13 \\
\hline $25^{\text {th }}$ percentile & & -20397 & -1209 \\
\hline $75^{\text {th }}$ percentile & & 0 & 238 \\
\hline \multicolumn{2}{|c|}{ Regression coefficient } & & $\begin{array}{c}0.882^{* * *} \\
(0.102)\end{array}$ \\
\hline
\end{tabular}

Notes to Table: The sample is as in our wealth effects regressions. Number of observations: 6370 observations, (3047 in 2008 and 3323 in 2010) from 3867 families. 441 households in 2008 and 475 in 2010, were share owners in 2006.

Monetary values are in 2010 euros. The regression coefficient is obtained by OLS regression of the change in reported wealth on the constructed change in wealth (and a constant).

Comparisons between changes in reported wealth and in "calculated" wealth give us an initial indication of how households responded to the asset price crash in their wealth and portfolio decisions. Table 2 describes the distribution of changes in reported and "calculated" wealth. On average, financial wealth decreases by almost 1300 euros in 2008 (i.e. between 2006 and 2008) and recovers by around half this amount in 2010. This trend is largely driven by a large fall in the value of risky financial wealth for owners of risky assets. Households that owned these risky assets in 2006 report an average decline in the value of their risky financial wealth between 2006 and 2008 of almost 25000 euro. Since around 
$14 \%{ }^{21}$ of households in the 2008 sample had risky assets in 2006 , this decline would average to a fall of 3600 euros across all households. ${ }^{22}$ There is also a decline in the value of risky wealth between 2008 and 2010, but the fall is much less precipitous.

Changes in reported and "calculated" wealth are sensibly different. Reported changes in financial wealth are, on average, less negative than their calculated counterpart, possibly because capital losses are partially offset by active saving. On the other hand, the reported change in risky assets is more negative than the "calculated change". This may indicate portfolio reshuffling by households, to reduce exposure to stock-market risk. This idea is also supported by observed exits from the stock market during the crisis: the stock-market participation rate decreases from $14 \%$ before 2006 to $12 \%$ in 2008 and to $10 \%$ in $2010 .{ }^{23} \mathrm{~A}$ regression of reported changes in wealth on calculated changes and a constant gives significant coefficients of 0.65 for overall wealth and 0.88 for risky wealth. Thus calculated changes in wealth do have the desired positive correlation with actual changes, and the relationship is closer for risky than for overall wealth.

\section{Measuring wealth effects}

Our main results are based on the IV estimator described in Section III. In line with equations (2) and (3), all our regressions include several independent $(\boldsymbol{X})$ variables alongside the key financial wealth measures.

When thinking about wealth effects, a variable of interest is the change in the household's housing wealth. We simply include the change in the reported value of housing

\footnotetext{
${ }^{21} 441$ out of 3047: see notes to Table 2.

$2224957 *(441 / 3047)=3612$.

${ }^{23}$ These ownership rates are calculated by the authors using the SHIW data (with sample as used in Table 1). Note that the ownership rates cannot be inferred from the numbers in Table 2 because the sample "with risky assets" in that Table are those that had risky assets in 2006 (when the ownership rate was approximately 14\%).
} 
since this should be the perceived value that informs consumption choices. Regarding exogeneity, since real-estate wealth is not readily adjustable, for housing there is less of a problem of a mechanical relationship between active saving and changes in consumption.

The remaining regressors include changes in: unemployment status; retirement status; and, in the number of people and earners living in the household. In addition, we control for homeownership, retirement status and employment in the private or public sector (all measured at time $t-1$ ), and for age bands, sex, education levels (compulsory, postcompulsory, and some college education). To capture effects coming from the state of the macroeconomy, we include region dummies, year and the regional unemployment rate.

Finally, we report results that control for the change in labour income, but have repeated all analyses without this regressor. There is a worry that labour income may be endogenous (due, for example, to reverse causality from the desire to increase or reduce consumption to labour effort and therefore income) so it is reassuring that the inclusion of the change in labour income does not noticeably affect the other estimated coefficients in the model, and particularly the estimated wealth effects (results with and without the change in labour income are in Online Appendix Tables D4-D7). With the exception of the financial wealth variables already described in Table 2, descriptive statistics for all regressors are contained in Online Appendix Table D1.

\section{Average responses to the wealth shock}

Our first set of results, in Table 3, has the change in total household consumption spending (col. 1 and 2) and the change in household consumption spending on non-durables (col. 3 and 4) as dependent variables. We present the "second stage" results of the IV regression for two alternative definitions of our main variable of interest: in columns 1 and 3 the financial wealth variable is the change in risky financial wealth that is invested in the stock 
market either directly or through a wrapper product such as a mutual fund, while in columns

2 and 4 it is the change in total (accessible ${ }^{24}$ ) household financial wealth.

Table 3: Wealth effects IV regressions for total and non-durable household consumption

\begin{tabular}{|c|c|c|c|c|}
\hline \multirow[b]{2}{*}{ Delta risky financial wealth } & \multicolumn{2}{|c|}{$\Delta$ total household expenditure } & \multicolumn{2}{|c|}{$\begin{array}{c}\Delta \text { household expenditure } \\
\text { on non-durables }\end{array}$} \\
\hline & $\begin{array}{l}0.088^{*} \\
(0.047)\end{array}$ & & $\begin{array}{l}0.057 * * \\
(0.028)\end{array}$ & \\
\hline Delta total financial wealth & & $\begin{array}{r}0.100 \\
(0.070)\end{array}$ & & $\begin{array}{c}0.062 * \\
(0.036)\end{array}$ \\
\hline Delta house value & $\begin{array}{l}0.003 * * * \\
(0.001)\end{array}$ & $\begin{array}{r}0.001 \\
(0.002)\end{array}$ & $\begin{array}{l}0.002 * * * \\
(0.001)\end{array}$ & $\begin{array}{r}0.001 \\
(0.001)\end{array}$ \\
\hline Delta labour income & $\begin{array}{c}0.079 * * * \\
(0.020)\end{array}$ & $\begin{array}{r}0.042 \\
(0.037)\end{array}$ & $\begin{array}{c}0.058^{* * *} \\
(0.016)\end{array}$ & $\begin{array}{r}0.035 \\
(0.022)\end{array}$ \\
\hline Delta unemployment status & $\begin{array}{l}-1481.319 * * \\
(618.512)\end{array}$ & $\begin{array}{l}-1427.671 * * \\
(659.231)\end{array}$ & $\begin{array}{l}-1123.289 * * * \\
(401.656)\end{array}$ & $\begin{array}{l}-1092.602 * * \\
(429.604)\end{array}$ \\
\hline Delta retirement status & $\begin{array}{r}569.728 \\
(480.620)\end{array}$ & $\begin{array}{r}446.971 \\
(733.326)\end{array}$ & $\begin{array}{l}-271.566 \\
(324.924)\end{array}$ & $\begin{array}{l}-352.157 \\
(481.610)\end{array}$ \\
\hline Delta no. of people in the $\mathrm{HH}$ & $\begin{array}{l}1930.572 * * * \\
(292.252)\end{array}$ & $\begin{array}{l}2005.018 * * * \\
(305.885)\end{array}$ & $\begin{array}{l}1731.445 * * * \\
(214.925)\end{array}$ & $\begin{array}{l}1780.590 * * * \\
(222.560)\end{array}$ \\
\hline Delta no. of earners in the $\mathrm{HH}$ & $\begin{array}{l}1039.473 * * * \\
(297.779)\end{array}$ & $\begin{array}{l}1168.668 * * * \\
(339.568)\end{array}$ & $\begin{array}{l}961.619 * * * \\
(223.897)\end{array}$ & $\begin{array}{l}1040.217 * * * \\
(240.356)\end{array}$ \\
\hline Year 2010 & $\begin{array}{r}224.320 \\
(580.768)\end{array}$ & $\begin{array}{r}-30.916 \\
(682.737)\end{array}$ & $\begin{array}{r}182.231 \\
(413.681)\end{array}$ & $\begin{array}{r}26.857 \\
(455.016)\end{array}$ \\
\hline
\end{tabular}

Notes to table: Number of observations: 6370 observations from 3867 families. Significance: ${ }^{*} p<0.1,{ }^{*} p<0.05$, *** $\mathrm{p}<0.01$. Standard errors in parenthesis are robust to heteroskedasticity and to correlation within the household.

Also included: homeownership, retirement and self-employment in the previous wave, age dummies (40-49, 50$59,60-69,70+)$, education dummies (medium and high education), gender, regional unemployment rate, regional dummies, constant term. Detailed results from the first stage regressions for the IV models are included in Online Appendix Tables D2 and D3; F-statistics from "weak instrument" tests are 14.61 for "Delta Risky Financial Wealth", and 5.11 for "Delta total financial wealth".

The coefficients on the main wealth variables should measure the mpc, which is the euro change in annual consumption spending per euro of change in wealth. For total consumption, the estimated mpc is 8.8 percent out of the shock to risky financial wealth, and 10 percent out of total financial wealth. For non-durable consumption, we obtain 5.7 percent out of the shock to risky financial wealth, and 6.2 out of total financial wealth. As a point of comparison, the estimated mpc for changes in financial wealth are considerably

\footnotetext{
${ }^{24}$ Accessible wealth excludes wealth "locked away" in pensions or life-insurance or similar products.
} 
larger than the results that we get for the propensity to consume out of a change in housing wealth, which is robustly estimated to be between 0.3 percent and 0.1 percent.

\section{Comparing these IV results to OLS estimates (reported in Online Appendix Tables D4-}

D7), one sees that the OLS results are always substantially smaller than the IV estimates. This

is in line with the arguments of the previous section that there are good reasons to expect

OLS estimation to underestimate this coefficient. ${ }^{25}$

We notice that the point estimates for the mpc are very slightly smaller but more

precisely estimated when the key independent variable is the change in risky financial wealth, compared to when it is the change in total financial wealth. For example, for total consumption, the estimated coefficient is 0.088 (significant at the $10 \%$ level) when the regressor relates to risky wealth, and 0.1 (not significant at conventional levels) when it relates to total financial wealth. The equivalent coefficients for non-durable consumption respectively are 0.057 (significant at the $5 \%$ level), and 0.062 (significant at the $10 \%$ level). The greater precision when the regressor is the change in risky wealth is partly due to the fact that we have a smaller standard error on the instrument in the first stage, which indicates that instrumenting adds less noise in this case. The larger size and higher precision of the estimated coefficient on the excluded variable in the case with risky wealth again indicate (as noted in Section III) that there is a stronger relationship between asset prices

\footnotetext{
${ }^{25}$ We do not report the "reduced form" that relates the change in consumption to the excluded instrument (and the other regressors). Given that we have one endogenous variable and exact identification, the coefficient on the wealth variable in this reduced form can be inferred as the product of the coefficients on the respective wealth variables in the first and second stages of the IV regression (this is the reverse of indirect least squares). Given that the coefficients in the first stages (reported in Online Appendix Tables D2 and D3) are 0.672 (for the change in risky wealth), and just below 0.6 (for the change in total financial wealth), the reduced form estimates would be smaller than our IV estimates. However, there are reasons to suppose that the reduced form would understate the relationship of interest. In particular: the change in calculated wealth is likely to overstate the true shock to wealth (and thus lead to an understatement of effects measured per euro of change in wealth) if households can offset some of the asset price shock through their portfolio choices; and, the reduced form would be affected by attenuation bias if there is measurement error. These issues were discussed in more detail in Bottazzi, Trucchi and Wakefield (2013).
} 
and the value of risky wealth than between asset prices and the value of all financial wealth, perhaps because portfolio reshuffling and the accumulation of safe assets weaken the relationship to total wealth. The F-statistic on the excluded instrument also indicates that our IV strategy is more effective when the regressor is the change in risky wealth: in that case we do not need to worry about a weak instrument problem. Full first-stage results are reported in Online Appendix Tables D2 (risky financial wealth) and D3 (total financial wealth).

Other than the estimated wealth effects, the other coefficients that are reported in Table 3 are coefficients on the variables that we most often found to be significant (full results are in Online Appendix Tables D4 to D7). The patterns of results are in line with economic intuition: becoming unemployed (but not becoming retired) is associated with cuts in spending, while the addition of extra household members or of an extra earner is linked to higher expenditures.

As already noted, the wealth effect coefficients are robust to controlling for the change in labour income. We also found that our estimates were not substantially affected by: having a more restricted sample (including using only the 2006-2008 period of the asset price shock) ${ }^{26}$ slightly modifying the implementation of our IV strategy; ${ }^{27}$ or, modifying the set of covariates included in our regressions. ${ }^{28}$ This extensive set of modifications to our

\footnotetext{
${ }^{26}$ Other changes in the sample selection come from running the regressions based on delta risky wealth only on those who have risky wealth, or from restricting to a sample that might have less concern about the riskiness of future income or employment because they work in the public sector or have pension income. ${ }^{27}$ The modification involves including the (twice-lagged) level of wealth in different assets and the interaction of this with the FTSEMIB stock-market index, in place of the constructed change in wealth as excluded variables in the first stage of our analyses. This sometimes it improves the significance of results.

${ }^{28}$ In particular, dropping regressors for (lagged) retirement status, sector of employment, and homeownership, or adding the change in "safe" financial wealth (not instrumented) in the specifications that include the change in risky wealth as the key regressor. We also experimented with adding an indicator of being risk averse (based on responses to questions about how prepared households are to trade off higher expected returns against an increased probability of wealth loss) to our specifications, and this had no noticeable effect on our regression coefficients.
} 
specifications indicate that our results are robust. ${ }^{29}$

To summarise, the results discussed in this section give the average effect of the wealth shock on the consumption of households in our sample. Our favoured estimates indicate that a euro loss of risky wealth in the period of the stock-market crash led, on average, to an 8.8 cent cut in consumption, and 5.7 cents of this cut was in spending on non-durable goods. Point estimates for the response to the change in total financial wealth are slightly larger, but less precisely estimated.

\section{Results for Categories of Consumption Spending}

The previous subsection describes results for broad categories of consumption. Theoretical considerations that "luxuries are easier to postpone" (Browning and Crossley, 2000), and findings that households in temporarily straitened circumstances may postpone the renewal of durables rather than immediately cutting back on all spending (Browning and Crossley, 2009), mean it is interesting to look at finer categories. Our data measure spending on durables and on food.

Table 4: Wealth effect coefficients: IV regressions for categories of consumption expenditure

\begin{tabular}{r|c|c|c|c}
\hline \hline Dependent variable: & $\Delta$ Total C & $\Delta$ Non-durables & $\Delta$ Durables & $\Delta$ Food \\
\hline & (a) & (b) & (c) & (d) \\
\hline Delta risky financial wealth & $\mathbf{0 . 0 8 8 ^ { * }}$ & $\mathbf{0 . 0 5 7} * *$ & $\mathbf{0 . 0 3 1}$ & $\mathbf{0 . 0 1 5 ^ { * }}$ \\
& $\mathbf{( 0 . 0 4 7 )}^{*}$ & $\mathbf{( 0 . 0 2 8 )}$ & $\mathbf{( 0 . 0 4 1 )}$ & $\mathbf{( 0 . 0 0 8 )}$ \\
Delta house value & $0.003^{* * *}$ & $0.002^{* * *}$ & 0.001 & 0.000 \\
& $(0.001)$ & $(0.001)$ & $(0.001)$ & $(0.000)$ \\
\hline
\end{tabular}

Notes to table: As for Table 3. In addition: regressors include all those reported in, or listed in the notes to, Table 3; for all specifications in this table the F-statistic from a "weak instrument" test is 14.61.

Table 4 presents key coefficients for our wealth effect regressions for spending on food and durables, alongside the results for total spending and spending on non-durables already presented in Table 3 (full sets of coefficients from the regressions are presented in Online

\footnotetext{
${ }^{29}$ Full results from the robustness checks just described, are available from the authors on request.
} 
Appendix Table D8). We present results from the IV specification and with the key

independent variable being the change in risky wealth (so that we do not have a problem of weak instruments)..$^{30}$

The point estimates in column (c) of the table indicate that durables expenditures were affected by, on average, 3.1 cents per year for a euro change in risky wealth. Since total consumption spending is the sum of spending on durables and spending on non-durables, the change in total spending per euro change in wealth should be the sum of the changes in spending on non-durables and durables, and we can see that this relationship does indeed hold. While this "adding up" is reassuring about the consistency of our data, the results for durables spending are not significant. The lack of significance may in part be due to the fact that durable purchases happen only infrequently and so we do not observe enough durables purchases to identify patterns in the data.

For food spending, a euro change in the value of risky financial wealth is seen to lead to a cut of 1.5 cents per year and this is significant at the $10 \%$ level. This result is potentially striking: if food is a necessity, then even small changes in food spending could be potentially important for households' welfare. However, we should be careful in interpretation since our data on food spending are not very disaggregated and we cannot, for example, distinguish "food in" and "food out". ${ }^{31}$

\section{How Large are these Wealth Effects?}

Our estimates of wealth effects in consumption exploit the 2007-08 shock to the financial asset prices in order to have a plausibly exogenous source of variation in wealth. Our

\footnotetext{
${ }^{30}$ Given that the sample and regressors (including the endogenous regressor) do not change across the regressions reported, the "first stage" results are always those already discussed and presented in Online Appendix Table D2.

${ }^{31}$ Based on a different dataset (a Household Budget Survey), Rondinelli (2014) does notice, for some groups of the population, differences in the evolution of expenditure shares on "food" and on "accommodation services and restaurants" during the 2000s (until 2012).
} 
estimated mpc may have generality outside our sample period, or it may be that the time period that we exploit is unusual in terms of average wealth effects. While we cannot investigate this directly, we can put our estimates in to context. We provide context by: (a) comparing our estimates to those from existing literature; (b) assessing how important wealth effects are for explaining consumption changes in our sample; and, (c) comparing our results to the predictions of a forward-looking consumption-saving model that is structured to capture elements of the period we investigate.

(a) Our estimates and existing literature. Findings regarding wealth effects in consumption have usually focussed on broad measures such as total consumption or non-durable consumption. The consumption responses that we find are stronger than the Italy-based findings of Guiso, Paiella and Visco (2005) that consumption may even fall in response to capital gains on financial assets, or of Paiella and Pistaferri (2017) of mpc of around 3\% almost entirely driven by responses to changes in the values of real (i.e. non-financial) assets. ${ }^{32}$ It seems likely that the difference of our results from these studies at least partly reflects our exploiting the asset price shock of 2007-2008.

It is slightly difficult to make a direct comparison of our results to those of Banks et al. (2012), the paper that is closest to ours in terms of methodology, since they do not observe such comprehensive measures of consumption spending as we do and their sample is restricted to the fifty-plus age range. In a simple lifecycle model, wealth shocks would be expected to lead to larger responses from older households that expect a shorter time horizon over which to spread the change in resources. ${ }^{33}$ However, relaxing the assumption

\footnotetext{
32 Paiella (2007) estimates a long-run marginal propensity for Italian households to consume out of net financial wealth of $9.2 \%$. This result exploits cross-sectional differences in wealth, while the results we cite in the text are, like our study, for capital gains or changes in wealth.

${ }^{33}$ This kind of intuition underlies much work trying to untangle why house price growth and aggregate consumption are so strongly correlated in the UK (see Attanasio and Weber, 1994; Attanasio, Blow, Hamilton and Leicester, 2009; Attanasio, Leicester and Wakefield, 2011).
} 
of unrestricted opportunities to borrow and save can substantially increase responses to shocks for younger households that are yet to establish a precautionary "buffer stock" of assets. In a lifecycle model that captures these elements and that can match high wealth inequality, Carroll et al. (2017) show that mpc out of resource (income) shocks can be relatively large for both older and younger households. To the extent that the results of Banks et al. (2012) can be compared to ours, their findings would seem to point to weaker effects than those that we find.

Compared to other, US based, results for wealth effects in the period since 2007, our mpc out of financial wealth is somewhat larger than the 3.3 percent found (again for an older sample) by Christelis, Georgarakos, and Jappelli (2015), but only slightly larger than the 5 - 7 percent mpc out of housing wealth estimated by Mian, Rao and Sufi (2013). More generally our findings on mpc out of shocks to financial wealth do not seem out of line with findings in the literature (see for example the collection of micro-data based results in Table 3 of Paiella, 2009), although our reading is that an estimate of almost $9 \%$ for total consumption is towards the top end of the range.

(b) To what extent do wealth effects explain consumption changes in our sample? Another way of thinking about the size of our estimated $\mathrm{mpc}$ is to consider what they imply for how much smaller observed falls in consumption would have been if the value of financial assets had not fallen in 2008. We therefore perform counterfactual simulations based on our regression. This exercise compares the average predicted change in consumption from our regression, to the average predicted change when the change in wealth for individuals in our sample is set to zero. ${ }^{34}$ We can also compare this influence of wealth effects to the (similarly computed) impact of other regressors.

\footnotetext{
${ }^{34}$ The easiest way to perform this counterfactual analysis within the IV set up is to "manually" compute the two stages. That is, use a regression command to compute the first stage; predict the "change in wealth"
} 
Table 5 displays the results of this counterfactual exercise based on the regression for total consumption on risky wealth reported in Table 3. The two columns respectively report counter-factual predictions averaged across all households in our sample, and across the (approximately) half of the sample observed in $2006-08$, the period of large asset price shocks.

\section{Table 5: Counterfactual Exercises: Predicted Changes in Consumption}

\begin{tabular}{|c|c|c|c|c|}
\hline & \multicolumn{2}{|c|}{ Full Sample } & \multicolumn{2}{|c|}{ 2006-08 Sample } \\
\hline $\begin{array}{l}\text { Average observed change in total consumption } \\
\text { Counterfactual changes }\end{array}$ & -515 & $(100 \%)$ & -796 & $(100 \%)$ \\
\hline$\Delta$ risky financial wealth set to 0 & -425 & (83\%) & -619 & (78\%) \\
\hline$\Delta$ housing value set to 0 & -498 & (97\%) & -770 & (97\%) \\
\hline$\Delta$ labour income set to 0 & -437 & $(85 \%)$ & -753 & $(95 \%)$ \\
\hline$\Delta$ no earners in the $\mathrm{HH}$ set to 0 & -494 & $(96 \%)$ & -781 & $(98 \%)$ \\
\hline No unemployment & -464 & (90\%) & -748 & (94\%) \\
\hline$\Delta$ no earners set to 0 and no unemployment & -443 & $(86 \%)$ & -733 & $(92 \%)$ \\
\hline $\begin{array}{l}\Delta \text { no earners and } \Delta \text { labour income set to } 0 \\
\text { and no unemployment }\end{array}$ & -365 & $(71 \%)$ & -690 & $(87 \%)$ \\
\hline
\end{tabular}

Notes to table: These counterfactuals are based on the IV regression reported in column 1 of Table 3. The full sample size is 6370 while the 2006-08 sample has 3047 observations. The mean level of consumption is 17454 in the full sample and 17627 in the 2006-08 subsample. The percentages in parentheses are the percentage of the average observed change.

In our full sample the average two-year fall in annual consumption is 515 euros, which amounts to approximately 3\% of average consumption spending (of 17454 euro). The 515 euro fall is matched by the average prediction of consumption changes from our leastsquares regression. If we repeat the prediction exercise but with the change in risky wealth set to zero for those who have risky wealth, we find the average fall in consumption is reduced to 425 euros. Thus, wealth effects are explaining around 90 out of the 515 euro average fall, or approximately $17 \%$ of the fall in consumption on average. ${ }^{35}$ This is

\footnotetext{
variable that becomes an input in to the second stage; compute second-stage coefficients with another regression command. It is then straightforward to use the second-stage coefficients to make predictions based on actual values of the "change in wealth" variable, or with this variable set to zero.

${ }^{35}$ It may seem surprising that the change in the value of risky wealth is so powerful, when only around $14 \%$ of our sample held risky financial wealth before the asset price shock. However, the shock to wealth was large. The results from our first stage indicate that the asset price shock led to an average fall in the value or risky wealth of 7130 euros among households with some risky wealth before the crisis, and combining this with our
} 
substantially larger than the small effect of changes in housing wealth, and slightly larger than either the impact of changes in labour income, or of the joint impact of changes in the number of earners and in unemployment status.

Considering only the $2006-08$ sample, the average fall in consumption is now 796 euros (or around 4.5 per cent). ${ }^{36}$ In this case we see that the changes in financial wealth are driving more of the fall in consumption (around $22 \%$ of it) than are any of the other factors we consider through our counterfactuals: in this sample even the composite effect of changes in the number of earners and in unemployment and in labour income, is not as strong as the effect of the shock to wealth.

(c) Marginal propensities to consume from a consumption-savings model. We consider a dynamic-stochastic lifecycle consumption-savings model that allows us to explore whether the marginal propensities to consume that we estimate are in line with the predictions of a forward-looking model. The model that we use builds on a standard buffer-stock savings set up with zero borrowing (early contributions of this type include Deaton, 1991, and Carroll, 1997) and a finite length of life. However, in order to have a model that allows us to assess marginal propensities to consume following a large shock to wealth, we implement some adaptations to standard models.

In particular, we construct a model with a stochastic process for the return to financial assets that admits the possibility of large shocks to wealth as a low probability event taken into account by agents with rational expectations. Parameters for the stochastic process for asset returns are chosen to match moments of the data, and we also match the stochastic process for income to the Italian case (as described econometrically by Bucciol, 2012). As is

mpc estimate gives an average cut in consumption due to the wealth shock of 627 euros per year among these households. Averaging the size of the cut across all households (with and without risky wealth) gives the 90 euro result.

${ }^{36}$ Since there is a " 2010 dummy", this fall is again matched exactly by regression predictions. 
well known, models of this kind cannot be solved analytically and the model is solved numerically and simulated. Full details of our model, including its parameterization and the results of our simulation runs, are in Online Appendix C.

Using the model, we can generate exact marginal propensities to cut consumption following a negative wealth shock for a population of simulated agents, and compare these to our estimates. The results of this exercise show that our empirical findings are in line with the mpc predicted by the model: the baseline run of the model gives an average mpc of 9.0\%. This baseline simulation result is left almost unaffected by changing the variance of the asset return, and is only somewhat affected by changing preference parameters governing risk aversion and patience (see Online Appendix Table C2). ${ }^{37}$

In sum, our estimated mpc are towards the top end of the range of estimates from the literature and substantial enough to explain an important part of consumption changes in our sample, but they could easily be generated by the consumption savings choices of rational, forward looking agents.

\section{Wealth Effects and Wealth Levels}

In the model discussed in the previous subsection, buffer-stock savings motives are important in generating $\mathrm{mpc}$ that can exceed the annuitized value of the wealth loss: ${ }^{38}$ households with relatively small precautionary balances respond strongly because the wealth shock sharpens the incentive to move away from the credit constraint by saving. The point that low wealth holdings and precautionary motives can be important in shaping consumption responses has recently been made forcefully by Carroll et al. (2017). In a rich

\footnotetext{
${ }^{37}$ Within the model we also looked at how mpc varied with the level "optimism" about the expected return on financial assets, and found that lower expected returns are associated with somewhat higher $\mathrm{mpc}$ (for details see Bottazzi, Trucchi and Wakefield, 2017b).

${ }^{38}$ How this shows up in our model is discussed in more detail in Online Appendix C, see p.9 of our supplementary material.
} 
model set up those authors show that the presence of households with low wealth and strong precautionary motives can have a noticeable impact on the average $\mathrm{mpc}$, and this could explain why micro estimates of the average mpc from a resource shock often substantially exceed the predictions of commonly used macro models. ${ }^{39}$ The role of constraints in consumption responses has also been emphasized by Kaplan and Violante (2014). They show that in a model with liquid and illiquid assets, constraints may affect behaviour even for households who are wealthy (and, potentially, relatively high income) if those households have small liquid balances. Regarding the extent of cut back in consumption in the US during the Great Recession, Mian, Rao and Sufi (2013) and Mian and Sufi (2014) have argued that the exposure of low wealth or (particularly) indebted households to losses in housing wealth, and strong consumption responses (high $\mathrm{mpc}$ ) by these households, played an important role. ${ }^{40}$

We use two extensions to our regressions to look at whether households with lower wealth, or indebted households, responded particularly strongly to the wealth shock. ${ }^{41}$ First, we split the sample into different groups according to the level of accessible household financial wealth (net of any debt), and estimate our IV regressions on the separate subsamples. The groups are the bottom half of the net wealth distribution (households with no more than approximately 6500 euro of accessible net financial wealth), and the top two

\footnotetext{
${ }^{39}$ Using Italian data, Jappelli and Pistaferri (2014) show that, responding to a question about a hypothetical transitory income shock, agents report relatively high $\mathrm{mpc}$ and higher reported $\mathrm{mpc}$ are associated with lower 'cash-on-hand'.

${ }^{40}$ The mechanisms underlying the role of "levered losses" in generating strong consumption responses are discussed at length in Mian and Sufi (2014), while evidence on the stronger consumption responses of more indebted households is presented in Mian, Rao and Sufi (2013).

${ }^{41}$ In this section we look at heterogeneity in wealth effects. In a previous versions of this work we also looked at heterogeneity with age (Bottazzi, Trucchi and Wakefield, 2017(a)) and by expectations about stock market returns (Bottazzi, Trucchi and Wakefield, 2017(b)). Heterogeneity by age, and the role of expectations, have also been important in literature on the relationship between house prices and consumption in the U.K. (see, Attanasio and Weber, 1994; Attanasio, Blow, Hamilton and Leicester, 2009; Disney, Gathergood and Henley, 2010; Attanasio, Leicester and Wakefield, 2011).
} 
quartiles of the distribution (with the split between the two groups at around 23000 euro of wealth). Results for total, non-durable and durable consumption are reported in Table 6.

Second, we introduce an indicator for holding a mortgage, and the interaction of this with our financial wealth variable, into our baseline specification; Table 7 reports results for total, nondurable and durable spending.

Table 6: Wealth effect coefficients with sample split by level of initial net financial wealth: instrumental variables regressions

\section{Coefficient on Delta risky financial wealth}

\begin{tabular}{l|c|c|c}
\hline $\begin{array}{l}\text { Initial net financial } \\
\text { wealth: }\end{array}$ & Below median & $\begin{array}{l}\text { Median - 75 } \\
\text { percentile }\end{array}$ & $\begin{array}{c}\text { Above 75th } \\
\text { percentile }\end{array}$ \\
\hline Dependent variable: & & & $0.115^{*}$ \\
\hline$\Delta$ total consumption & 0.021 & 0.214 & $(0.066)$ \\
\hline$\Delta$ non-durable & $(0.018)$ & $(0.285)$ & $0.066^{*}$ \\
consumption & 0.014 & 0.015 & $(0.037)$ \\
\hline$\Delta$ durable consumption & $(0.015)$ & $(0.133)$ & 0.050 \\
& 0.007 & 0.199 & $(0.062)$ \\
\hline \hline N. observations & $(0.009)$ & $(0.215)$ & 1591 \\
Own risky financial assets & 3186 & 1593 & $40.16 \%$ \\
\hline \hline
\end{tabular}

Notes to table: Significance: $* \mathrm{p}<0.1, * * \mathrm{p}<0.05, * * * \mathrm{p}<0.01$. Standard errors in parenthesis are robust to heteroskedasticity and to correlation within the household.

Reported coefficients can be interpreted as mpc out of wealth change. Also included: a constant; delta house value and delta labour income; homeownership, retirement and self-employment in the previous wave; age dummies (40-49, 50-59, 60-69, $70+$ ), education dummies (medium and high education), gender, regional unemployment rate, region, 2010 dummy; change in: unemployment status, retirement status, no. of people in the household, no. of earners in the household. F-statistics from "weak instrument" tests are: 4.74 ("below median" column), 3.25 (median - 75 ${ }^{\text {th }}$ percentile), 26.71 (above $75^{\text {th }}$ percentile).

Looking at the results in Table 6, we see very small mpc in the lowest wealth group.

However, this is a group with very low levels of financial wealth and very low exposure to stock market risk (less than $4 \%$ held risky assets), and so shocks to wealth that could drive consumption in this group are limited. Of more interest are the results for the higher wealth groups that were more exposed to the shock of falling asset prices. For total consumption we see point estimates that indicate smaller responses in the top wealth group than in the middle wealth group; the other results in the table indicate that this pattern of point estimates is related to responses in durables spending. The pattern is also evident in the 
"reduced form" versions of the regressions, ${ }^{42}$ which reassures us that the differences are not due to a weak instrument in the middle wealth group (where only $10 \%$ are exposed to risky assets) leading to exaggerated estimates. On the other hand, given that we cannot reject that $\mathrm{mpc}$ are equal across wealth groups, care should be taken in interpreting the differences in point estimates. The point estimates for total consumption are consistent with lower-wealth households responding more strongly when exposed to a resource shock, but we do find detectable responses from wealthier households (who were most exposed to the shock) that are important in generating the effects identified in our baseline regressions.

\section{Table 7: Wealth effect coefficients: IV regressions; heterogeneity by leverage} position

\begin{tabular}{|c|c|c|c|c|c|c|}
\hline \multirow[t]{2}{*}{ Dependent variable: } & \multicolumn{2}{|c|}{$\Delta$ total consumption } & \multicolumn{2}{|c|}{$\Delta$ non-durable cons. } & \multicolumn{2}{|c|}{$\Delta$ durable consumption } \\
\hline & $\begin{array}{c}\text { No Control } \\
\text { for } \\
\text { mortgage }\end{array}$ & $\begin{array}{c}\text { Control for } \\
\text { mortgage } \\
\text { holding }\end{array}$ & $\begin{array}{c}\text { No Control } \\
\text { for } \\
\text { mortgage }\end{array}$ & $\begin{array}{c}\text { Control for } \\
\text { mortgage } \\
\text { holding }\end{array}$ & $\begin{array}{c}\text { No Control } \\
\text { for } \\
\text { mortgage }\end{array}$ & $\begin{array}{c}\text { Control for } \\
\text { mortgage } \\
\text { holding }\end{array}$ \\
\hline $\begin{array}{l}\text { Delta risky financial } \\
\text { wealth }\end{array}$ & $\begin{array}{c}0.088 * \\
(0.047)\end{array}$ & & $\begin{array}{l}0.058^{* *} \\
(0.028)\end{array}$ & & $\begin{array}{r}0.030 \\
(0.041)\end{array}$ & \\
\hline $\begin{array}{l}\Delta \text { risky fin. wealth: } \\
\text { HH w/out mortgage }\end{array}$ & & $\begin{array}{l}0.080 * \\
(0.047)\end{array}$ & & $\begin{array}{c}0.053 * \\
(0.028)\end{array}$ & & $\begin{array}{r}0.027 \\
(0.041)\end{array}$ \\
\hline $\begin{array}{l}\Delta \text { risky fin. wealth: } \\
\text { Mortgage holders }\end{array}$ & & $\begin{array}{r}0.239 \\
(0.207)\end{array}$ & & $\begin{array}{c}0.148 * \\
(0.090)\end{array}$ & & $\begin{array}{r}0.091 \\
(0.143)\end{array}$ \\
\hline Hh has a mortgage & & $\begin{array}{l}988.966 * \\
(533.65)\end{array}$ & & $\begin{array}{l}792.330 * * \\
(354.97)\end{array}$ & & $\begin{array}{l}196.636 \\
(352.66)\end{array}$ \\
\hline
\end{tabular}

Notes to table: Observations: 5536 from 3630 families. Significance: ${ }^{*} p<0.1,{ }^{* *} p<0.05,{ }^{* * *} p<0.01$. Standard errors in parenthesis are robust to heteroskedasticity and to correlation within the household.

Also included: a constant; delta house value and delta labour income; homeownership, retirement and self-employment in the previous wave; age dummies (40-49, 50-59, 60-69, 70+), education dummies (medium and high education), gender, regional unemployment rate, region, 2010 dummy; change in: unemployment status, retirement status, no. of people in the household, no. of earners in the household. F-statistics from "weak instrument" tests are: 14.54 when not controlling for mortgage holding (1st stage for columns 1, 3 and 5); and, 8.00 (Delta risky financial wealth) and 2.12 (interaction) when controlling for mortgage holding (1st stages for columns 2, 4 and 6).

In Table 7, alongside the regressions that interact the wealth variable with the indicator for holding a mortgage, we report new versions of the baseline regressions that are based on the subsample for which the mortgage indicator is available. While some care is again

\footnotetext{
${ }^{42}$ The estimated coefficients for the reduced form of the total consumption regression are 0.233 and 0.056 (the latter significant at the $10 \%$ level); full reduced form results are available on request.
} 
needed with interpretation since tests indicate a weak instruments problem for the interaction terms, there is a clear pattern of point estimates that suggests that households that have mortgages responded more strongly to the wealth shock. ${ }^{43}$ Thus our results are in line with the idea that indebted households respond more strongly to shocks to wealth (or at least to a negative shock to wealth). On the other hand, we do also see significant responses from households that did not have mortgage debt. In our sample only around 1 in 7 of those who suffered losses in risky financial wealth were exposed to mortgage debt, and so the behaviour of those without such debt is important in driving the changes identified in our baseline results.

Looking at subgroups within our sample, we find tentative evidence in line with the idea of stronger consumption responses from those with lower net wealth or greater exposure to debt. This is in line with other studies and theoretical considerations suggesting that the economic relevance of resource shocks may depend on how these are distributed across households with different precautionary balances.

\section{Conclusions}

We have used the large shock to the financial asset values in 2007-08 as a plausibly exogenous source of variation in wealth, in an IV estimate of the marginal propensity to consume out of shocks to financial wealth. Our findings indicate that a one-euro fall in risky financial wealth resulted in households cutting annual total consumption spending by between 8.5 and 9 cents, and slightly more than 5.5 cents of this cut was in spending on non-durable goods and services. We find effects of around 1.5 cents for food spending, and

\footnotetext{
${ }^{43}$ In contrast to the results in Table 6, in this case the pattern is evident in non-durable spending as well as in total and durable spending. Splitting the sample by mortgage holding does not fully overlap with splitting by net wealth: exposure to mortgages is only slightly lower in the top net wealth quartile (at $5 \%$ ) than in the third quartile (6\%).
} 
insignificant results (though with the expected positive coefficients) for expenditure on durables.

Our results are perhaps towards the top end of the range of past estimates of similar parameters. To further quantify the importance of our estimates, we constructed counterfactuals that simulate how much of the average fall in consumption in our sample is accounted for by shocks to financial wealth. The average proportional fall in consumption for individuals in our sample was reasonably in line with the fall in aggregate consumption in the Italian economy, and the counterfactual exercise indicates that for these individuals around 17 to 22 percent of the fall in consumption was a response to shocks to the value of financial wealth. This average effect is at least as large as the change in consumption spending accounted for by cuts in labour income or by the combined impact of changes in the number of earners and in unemployment status.

We also show that the propensities to consume that we estimate are consistent with the predictions of a dynamic-stochastic lifecycle consumption-savings model. The numerical model that provides these predictions embeds a stochastic process for the return to financial assets that admits the possibility of large shocks to wealth as observed in our data.

In the light of theoretical considerations, and other evidence, suggesting that the economic relevance of resource shocks may depend on how these are distributed across households with different precautionary balances, we look at whether responses to wealth shocks were stronger for lower-wealth households or those with mortgage debt. We find tentative evidence in line with the hypothesis, but also see that the responses of wealthier households and those without mortgages were important in generating our baseline results.

Applying our method requires a large shocks to asset prices. While we therefore need to be careful about claiming too much generality for our results, episodes of negative asset 
price shocks do make the study of wealth effects painfully relevant. Our findings that households did contract consumption due to wealth shocks highlight that wealth effects in consumption are important. They are important both for the welfare of households that suffer the shocks and as a mechanism through which such shocks feed back into aggregate consumption and economic activity.

\section{References}

Agenzia del Territorio (2012) "Rapporto Immobiliare - Il settore residenziale".

Attanasio, O. P., Blow, L., Hamilton, R. and Leicester, A. (2009), "Booms and busts:

Consumption, house prices and expectations", Economica 76, 20-50.

Attanasio, O. P., Leicester, A. and Wakefield, M. (2011), “Do house prices drive consumption growth? The coincident cycles of house prices and consumption in the UK", Journal of the European Economic Association 9, 399-435.

Attanasio, O. P. and Weber, G. (1993), “Consumption Growth, the Interest Rate and Aggregation", The Review of Economic Studies 60, 631-49.

Attanasio, O. P. and Weber, G. (1994), “The UK consumption boom of the late 1980's: aggregate implications of microeconomic evidence." The Economic Journal 104, 12691302.

Banks, J., Blundell, R. and Tanner, S. (1998), "Is there a Retirement-Savings Puzzle", American Economic Review 88(4), 769 - 788.

Banks, J., Crawford, R., Crossley, T. F. and Emmerson, C. (2012), The Effects of the Financial Crisis on Older Households in England, IFS Working Paper W12/09.

Bucciol, A. (2012), "Measuring the Income Process in Italy," Rivista di Politica Economica 102(1-3), pp. 175-196.

Bottazzi, R., Trucchi, S. and Wakefield, M. (2013), Wealth effects and the consumption of Italian households in the Great Recession, IFS Working Paper W13/21.

Bottazzi, R., Trucchi, S. and Wakefield, M. (2017a), Wealth effects and the consumption of Italian households in the Great Recession, University of Bologna, WP-DSE 1097.

Bottazzi, R., Trucchi, S. and Wakefield, M. (2017b), Consumption responses to a large shock 
to financial wealth: evidence from Italy, Economics Discussion Papers 20188, University of Essex, Department of Economics.

Browning, M. and Crossley, T. F. (2000), "Luxuries are Easier to Postpone: A proof”, Journal of Political Economy 108(5), October 2000, 1022-1026.

Browning, M. and Crossley, T. F. (2009), "Shocks, Stocks, and Socks: Smoothing Consumption Over a Temporary Income Loss," Journal of the European Economic Association 7(6), 11691192.

Calcagno, R., Fornero, E. and Rossi, M. (2009), "The Effect of House Prices on Household Consumption in Italy," The Journal of Real Estate Finance and Economics 39(3), 284 - 300.

Campbell, J. Y. and Mankiw, N. G. (1989), “Consumption, Income and Interest Rates:

Reinterpreting the Time Series Evidence", in NBER Macroeconomics Annual, Olivier J. Blanchard and Stanley Fischer (eds.), MIT Press: Cambridge MA.

Carroll, C. D. (1997), "Buffer Stock Saving and the Lifecycle/Permanent Income Hypothesis", The Quarterly Journal of Economics CXII (1), pp. 1-56.

Carroll, C. D., Otsuka, M. and Slacalek, J. (2011), "How Large Are Housing and Financial Wealth Effects? A New Approach", Journal of Money, Credit and Banking 43(1), 55-79.

Carroll, C. D., Slacalek, J., Tokuoka, K. and White, M. N. (2017), "The distribution of wealth and the marginal propensity to consume", Quantitative Economics 8, 977 - 1020.

Celidoni, M., De Nadai, M. and Weber, G. (2016), Consumption during the Great Recession in Italy, IFS Working paper W16/10.

Christelis, D., Georgarakos, D. and Jappelli, T. (2015), "Wealth Shocks, Unemployment Shocks and Consumption in the Wake of the Great Recession," Journal of Monetary Economics 72, 21-41.

Crawford, R. (2013), "The effect of the financial crisis on the retirement plans of older workers in England", Economics Letters 121, 156-159.

Crossley, T. F., Low, H. and O'Dea, C. (2013), “Household Consumption through Recent Recessions", Fiscal Studies 34(2), 203-229.

Deaton, A. (1991), “Saving and Liquidity Constraints", Econometrica 59(5), pp. 1221-1248.

De Nardi, M., French, E. and Benson, D. (2012), "Consumption and the Great Recession", 
Economic Perspectives 36(1), Federal Reserve Bank Chicago.

Disney, R., Gathergood, J. and Henley, A. (2010), “House Price Shocks, Negative Equity and Household Consumption in the United Kingdom", Journal of the European Economic Association 8(6), $1179-1207$.

Dynan, K. E. and Maki, D. M. (2001), Does Stock Market Wealth Matter for Consumption?, Board of Governors of the Federal Reserve Systems "FEDS" (Finance and Economics Discussion Series) paper 2001-23, May 2001.

Guiso, L., Paiella, M. and Visco, I. (2005), Do capital gains affect consumption? Estimates of wealth effects from Italian households' behaviour, Bank of Italy, Working Paper 555.

Jappelli, T. and Pistaferri, L. (2014), "Fiscal Policy and MPC heterogeneity", AEJ:

Macroeconomics 6(4), 107-136.

Kaplan, G. and Violante, G. L. (2014), "A model of the consumption response to fiscal stimulus payments", Econometrica 82(4), 1199-1239.

Mian, A., Rao, K. and Sufi, A. (2013), "Household Balance Sheets, Consumption, and the Economic Slump", The Quarterly Journal of Economics 128(4), 1687-1726.

Mian, A. and Sufi, A. (2014), House of Debt: How They (and You) Caused the Great Recession, and How We Can Prevent It from Happening Again, The University of Chicago Press, Chicago and London.

OECD, (2018), National Accounts of OECD Countries, Volume 2018 Issue 1: Main Aggregates, OECD Publishing, Paris, http://dx.doi.org/10.1787/na ma dt-v2018-1-en.

Paiella, M. (2009), "The Stock Market, Housing and Consumer Spending: A Survey of the Evidence on Wealth Effects", Journal of Economic Surveys 23(5), 947-73.

Paiella, M. (2007), "Does Wealth Affect Consumption? Evidence for Italy", Journal of Macroeconomics 29, 189-205.

Paiella, M. and Pistaferri, L. (2017), "The Anatomy of the Wealth Effect", The Review of Economics and Statistics 99(4), 710-721.

Petev, I., Pistaferri, L. and Saporta-Eksten, I. (2011) "Consumption and the Great Recession", D. Grusky, B. Western and C. Wimer (eds.), The Great Recession, CUP Services. 
Rodano, L. and Rondinelli, C. (2014), "The Italian household consumption: a comparison among recessions", Politica economica 2-3/2014, 203-234.

Rondinelli, C. (2014), “On the Structure of Italian Households: Consumption Patterns During the Recent Crises", Politica economica 2-3/2014, 235-260.

This article is protected by copyright. All rights reserved. 